\title{
Samoa: Assessment of Financial Sector Supervision and Regulation including Report on the Observance of Standards and Codes on Banking Supervision
}

This Assessment of Financial Sector Supervision and Regulation for Samoa was prepared by a staff team of the International Monetary Fund. It is based on the information available at the time it was completed on June 20, 2007. The views expressed in this document are those of the staff team and do not necessarily reflect the views of the government of Samoa or the Executive Board of the IMF.

The policy of publication of staff reports and other documents by the IMF allows for the deletion of market-sensitive information.

To assist the IMF in evaluating the publication policy, reader comments are invited and may be sent by e-mail to publicationpolicy@imf.org.

Copies of this report are available to the public from

International Monetary Fund $\bullet$ Publication Services

700 19th Street, N.W. • Washington, D.C. 20431

Telephone: (202) $6237430 \bullet$ Telefax: (202) 6237201

E-mail: publications@imf.org • Internet: http://www.imf.org

Price: $\$ 18.00$ a copy

\section{International Monetary Fund}

Washington, D.C. 


\title{
INTERNATIONAL MONETARY FUND
}

\section{SAMOA}

\section{ASSESSMENT OF FinANCIAL SECTOR SUPERVISION AND REgUlation}

\author{
Prepared by the Monetary and Capital Markets Department
}

\author{
Approved by Jaime Caruana
}

June 20, 2007

\begin{abstract}
This report is based primarily on work undertaken during a visit to Samoa during February 27 - March 8, 2007.
The assessment team comprised Mr. Salim M. Darbar (Head, MCM), Mr. Timothy M. Sullivan (consultant for banking), and Mr. Ronald J. MacDonald (consultant for banking). The assessment team received excellent cooperation from the authorities and market participants. The main findings of the assessment are:
\end{abstract}

- Samoa has taken steps to address many of the recommendations of the 2002 assessments to strengthen supervision of both international (offshore) and domestic banks.

- Compliance with the Basel Core Principles for banking supervision has improved considerably compared with the previous assessment for both international and domestic banks.

- Supervision of domestic banks has been strengthened mainly through the introduction of on-site examinations. Additional guidance should be issued to cover banks' credit and lending activities, and corporate governance.

- International banks are now required to establish a physical presence and on-site supervision has also been introduced. Additional prudential guidance on banks' lending and risk taking activities need to be issued.

- Consideration should be given to enhancing the operational independence of the Samoa International Finance Authority in supervising international banks.

The main author of this report is Salim M. Darbar with contributions from the rest of the team.

The AFSSR is a summary report on implementation of the indicated financial sector regulatory standards. It has been developed to help jurisdictions identify and remedy weaknesses in financial sector supervision and regulation. The reviews do not directly assess risks such as those associated with asset quality, markets, or fraud that could affect the soundness of financial systems or individual institutions. 


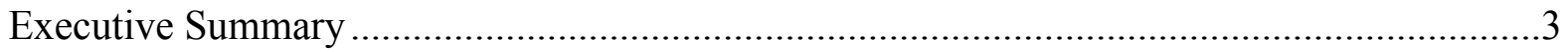

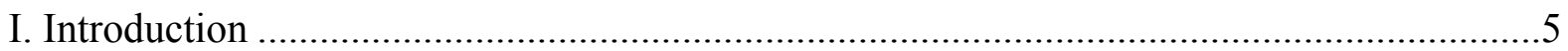

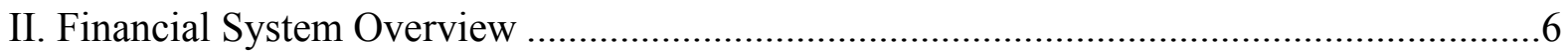

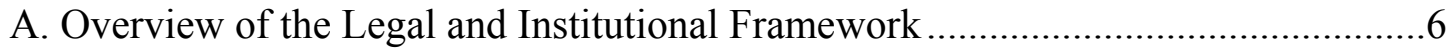

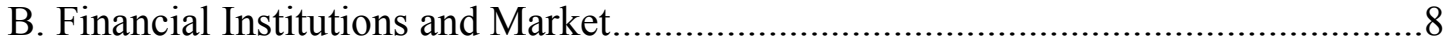

III. Findings from Earlier Assessments and Authorities Response ...................................10

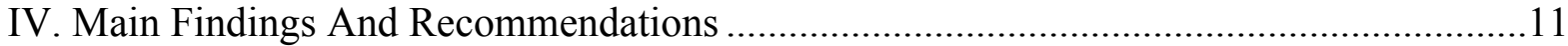

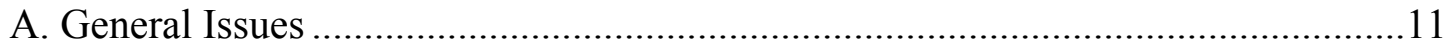

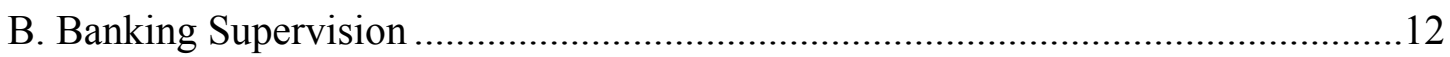

Text Table

1. Samoa: Structure of the Domestic Financial System, 2002-06 .....................................15

Appendices

I. Report on the Observance of Standard and Codes ................................................... 16

II. Actions Taken by the Samoan Authorities in Response to the 2002 Assessment ..............25

Appendix Tables

2. Domestic Banking Sector: Recommended Action Plan to Improve Compliance with the

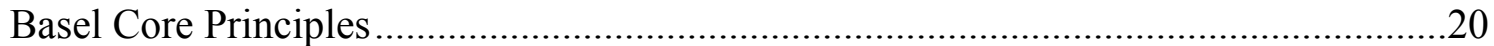

3. International Banking Sector: Recommended Action Plan to Improve Compliance with the

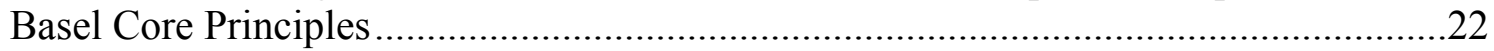




\section{EXECUTIVE SUMMARY}

Samoa has taken steps to address many of the recommendations of the 2002 assessment for strengthening the supervision of both offshore (international) and domestic banks. The authorities have prohibited shell banks and introduced physical presence requirements for all international banks. Supervision of domestic banks has been strengthened mainly through the introduction of on-site examinations.

The international banking sector is limited in size and scope. There are only six international banks, all of which are restricted operations limited to providing services to those persons or entities listed in the license application. None of the international banks accepts deposits from the nonresident public.

Compliance with the Basel Core Principles (BCPs) for the supervision of international and domestic banks has improved considerably since the previous assessment. However, while current supervisory arrangements are adequate given the limited scale of international banking, additional measures need to be taken to bring them fully into line with international standards. This is particularly necessary to counter reputation risk that could arise if supervisory standards are perceived to be lower than acceptable international levels. Also, supervision of domestic banks should be strengthened further through issuance of additional guidance on banks' risk taking activities and corporate governance.

Consideration should be given to enhancing the operational independence of Samoa International Finance Authority (SIFA) to supervise international banks. While there is no evidence of governmental interference in the day-to-day supervision undertaken by SIFA, the exclusive legal powers of the Minster of Finance to grant licenses and to take other important supervisory measures create room for possible governmental interference in supervisory decision making. In addition the potential for conflict between the promotional and supervisory roles of SIFA should be addressed.

The AML/CFT legislative framework was recently updated with the enactment of several pieces of legislation. The central bank should implement the new AML/CFT legislation by issuing expeditiously the supporting regulations and guidelines.

Box 1 below provides some key recommendations from the assessment. Additional recommendations are discussed in the main body of the report and in the Appendix. 


\section{Box 1. Priority Recommendations}

\section{General issues}

- Consideration should be given to enhancing the operational independence of SIFA in supervising international banks.

- Address the potential for conflict between the promotional and supervisory roles of SIFA.

- Consider disseminating aggregate data on the activities of the offshore sector.

- SIFA should put in place a comprehensive business continuity plan.

International banking

- Continue and expand monitoring of banks' activities and risk exposures through on-site examinations.

- Introduce minimum capital requirements for each bank based on its risk profile.

- Issue guidance on banks' policies, procedures, and systems related to risk management, as well as on their corporate governance.

\section{Domestic banking}

- Issue more detailed guidance on banks' credit polices.

- Strengthen monitoring and compliance on connected lending and large exposures.

- Introduce a requirement that banks have in place comprehensive risk management polices to control their non-credit risks (e.g., interest rate, market, operational, and country risks).

- Provide guidance to banks on establishment of corporate governance policies and procedures.

- Amend legislation to provide the central bank with the authority to effect change in banks' Boards of Directors and senior management.

- Implement the new AML/CFT legislative framework by issuing the supporting regulations and guidelines. 


\section{INTRODUCTION}

1. This report provides an assessment of the supervision of the banking system based on the Basel Core Principles for Effective Banking Supervision (BCPs). The assessment was conducted in accordance with the 1997 BCP and the accompanying Methodology (1999), and Appendix I contains the accompanying Report on Observance of Standards and Codes. In addition, advice on achieving compliance with the more recently revised 2006 BCP is provided in a separate Technical Note. The report also reviews developments in the offshore sector since the last assessment.

2. This assessment is a follow-up to the one undertaken in 2002 in the first phase of the offshore financial center (OFC) program. ${ }^{1}$ The 2002 assessment assessed compliance with the BCPs and evaluated the anti-money laundering and combating the financing of terrorism (AML/CFT) regime based on the Financial Action Task Force (FATF) 40+9 Recommendations. ${ }^{2}$ In February 2006, a mutual evaluation of Samoa's AML/CFT regime was jointly conducted by the Asia/Pacific Group on Money Laundering (APG) and the Offshore Group of Banking Supervisors (OGBS). ${ }^{3}$

\section{Economic background}

3. The main contributors to Samoa's economy are the manufacturing, construction, and tourism sectors. Traditionally the economy was more reliant on agriculture and fishing. The economy is also heavily dependent on remittances from abroad. Samoa is one of the highest recipients of remittances as a share of GDP amounting to about 24 percent in $2004 .{ }^{4}$ Official transfers from Australia, New Zealand, and Japan have also been significant in recent years.

4. In the past decade and a half, Samoa has achieved significant economic development with real per capita income increasing by about 3 percent per annum. Samoa's population was estimated at about 179,186 in 2006 with per capita GDP of US\$ 2,300 in $2005 / 06$. Factors that contributed to this achievement include prudent fiscal management, comprehensive structural reforms, and political stability. More recently, real GDP growth in 2005/06 has been fueled largely by construction activities related to the forthcoming South Pacific Games to be hosted by Samoa in September 2007. Private sector credit growth has been rapid (about 30 percent year-on-year; end-September 2006)

\footnotetext{
${ }^{1}$ In 2003 the IMF Executive Board agreed that the IMF should conduct periodic assessments (every 4-5 years) to monitor progress as well as ensure that good supervisory practice has been maintained. See PIN No. 03/138 at http://www.imf.org for a summary of the Executive Board discussion.

${ }^{2}$ The assessment was conducted on the basis of the 2002 Methodology.

${ }^{3}$ The mutual evaluation report is available at http://www.apgml.org/documents/docs/17/Samoa\%20ME2.pdf.

${ }^{4}$ See "Samoa--Staff Report for the 2005 Article IV Consultation" at http://www.imf.org/external/pubs/ft/scr/2005/cr05220.pdf.
} 
particularly for construction in anticipation of the South Pacific Games. To safeguard the external position monetary policy was tightened. Nevertheless, official reserves at end September 2006 declined to just below four months of import cover.

5. Although not a major sector of the economy, the offshore financial sector contributes to the Samoan economy in several ways. The offshore financial sector is a source of foreign exchange earnings, albeit a minor one compared to remittances and tourism. In 2005, it was the third highest earner of foreign exchange following remittances and tourism, and ahead of fishing. ${ }^{5}$ The offshore financial sector contributed roughly 1.1 percent of GDP, while the contribution of the total financial sector (both domestic and offshore) was 9.5 percent of GDP in 2005. More significantly, the offshore sector contributed 3.9 percent of fiscal revenue in $2005 / 06$. The number of personnel directly employed in the offshore sector - 36 persons at end February 2007 - is not large. ${ }^{6}$ However, the offshore sector also calls upon the services of lawyers, accountants, and auditors. Total employment in the financial sector stood at 1,142 persons in 2005 .

\section{Financial System OVERVIEW}

\section{A. Overview of the Legal and Institutional Framework}

6. The supervision of international financial services is the responsibility of the Samoa International Finance Authority (SIFA). SIFA was established in 2005 as an autonomous agency with the enactment of the SIFA Act 2005. SIFA replaced the Office of the Registrar of International and Foreign Companies, established in 1988, which was previously responsible for the supervision of the offshore sector. SIFA is broadly responsible for supervising entities that provide financial services to nonresidents including international banks, insurance companies, and trust and company service providers.

\section{SIFA is administered by a Board of Directors and managed by the Chief} Executive Officer (CEO). The Board of Directors consist of the Governor of the Central Bank of Samoa (CBS), the CEO of the Ministry of Finance, the Attorney General, the CEO of SIFA, and 3 Directors from the private sector. The Governor of the CBS is the chair of the Board. SIFA is free to set fees and charges and is not dependent on the government's budget. In fact it transfers surplus funds to the budget (see above).

\section{International banks are supervised under the provisions of the new} International Banking Act 2005 (IBA) enacted in May 2005 which replaced the Offshore Banking Act 1987. Under the IBA, responsibility for the regulation and supervision of international banks is shared between the Minister of Finance and the Inspector of International Banks appointed by the Minister and supported by SIFA personnel (the Inspector is also the chief executive of SIFA). The IBA assigns the legal power to

\footnotetext{
${ }^{5}$ Remittances amounted to approximately US\$100 million in 2005, while export receipt from fisheries and the gross revenues of SIFA were each only about US\$4 million.

${ }^{6}$ Employed by the trust and company service providers.
} 
license international banks to the Minister of Finance together with exclusive power to impose additional license conditions, to revoke licenses, to impose corrective measures, and to apply to the court for an international bank to be wound up. Under the IBA it is the duty of the Inspector to carry out day to day supervision of international banks' operations and to make recommendations to the Minister on applications for licenses and license renewals.

9. Under the IBA all licensees must establish a physical presence in Samoa. Physical presence is defined in the law as a place of business maintained by the international bank and located at a fixed address, other than a post office box or electronic address in Samoa and at which the bank: (i) employs one or more individuals full-time; and (ii) maintains operations and banking related records. In addition, according to the new law an international bank must have not less than two directors, at least one of whom must be a resident of Samoa. However, there is still no requirement that mind and management must reside in Samoa.

10. The other main pieces of legislations that govern the regulation and supervision of international financial services are: the International Companies Act 1987; the International Insurance Act 1988; the International Trusts Act 1987 and the Trustee Companies Act 1987; the International Partnership and the Limited Partnership Act 1998; and the Segregated Fund International Companies Act 2000. ${ }^{7}$

11. The AML/CFT legislative framework was updated with the enactment of the Money Laundering Prevention Act 2007, the Mutual Legal Assistance on Criminal Matters Act 2007, and the Proceeds of Crime Act 2007. Supporting regulations and guidance to implement these Acts are being prepared and are expected to be issued later this year. The relevant agencies for implementing the AML/CFT regime include the CBS, SIFA, the Financial Intelligence Unit (FIU) which was established within the CBS, the police, the customs, the attorney general's office and the judiciary.

12. Domestic financial services are supervised by the CBS. The legal framework governing the supervision of the domestic financial sector is the CBS Act 1984 and the Financial Institutions Act 1996 (FIA). The latter provides the necessary authority for the CBS to supervise domestic commercial banks.

13. The CBS is also the supervising agency for domestic nonbank financial services in accordance with an amendment to the FIA in 2001. This amendment extended the definition of financial services thereby allowing the Minister of Finance to transfer the mandate for supervising the insurance industry, the National Provident Fund, and the Development Bank of Samoa to the CBS. Under the provisions of the Insurance Act 1976 the Minister of Finance is responsible for the licensing and supervision of insurance companies. A new draft Insurance Act has been submitted to parliament and could be enacted as early as April 2007. The new Insurance Act would provide the CBS with the appropriate legislative

\footnotetext{
${ }^{7}$ For a brief description of these Acts see Box 1 in the 2002 assessment at http://www.imf.org/external/pubs/ft/scr/2004/cr04171.pdf.
} 
framework to license and supervise the domestic insurance industry. The National Provident Fund and the Development Bank are governed by their own Acts.

\section{B. Financial Institutions and Market}

\section{The size and scope of offshore}

banking is limited. There were six

Number of International Banks, 1989-2007

international (offshore) banks at end-2006. The number of international banks peaked at 18 in 1997 and has declined owing to tighter regulatory controls introduced in 1998 and in 2005. The international banks were given a transitional period of about 9 months following the enactment of the IBA in May 2005 to establish physical presence. Two banks complied in advance of the

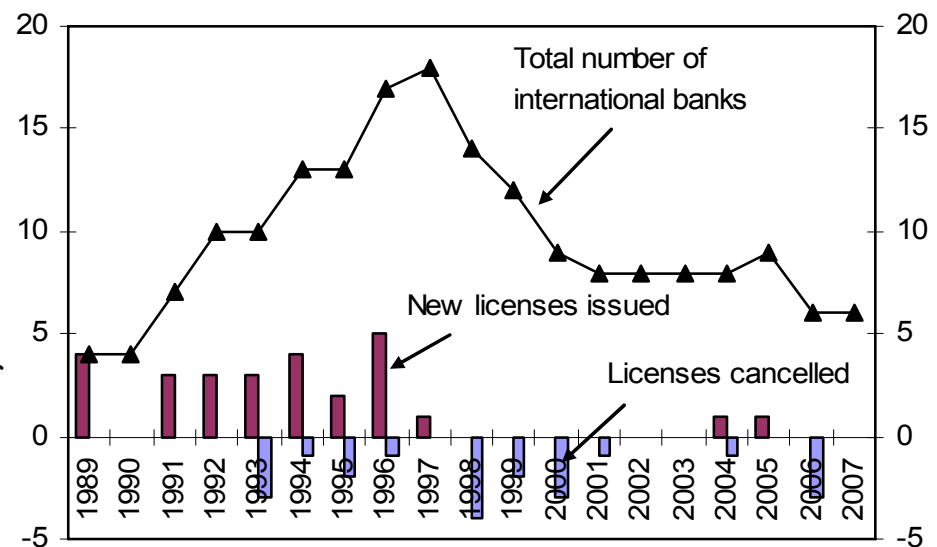
enactment date of the IBA; two complied within the transitional period; and two were granted an extension until July 2006 to comply. All six banks have now established physical presence. The licenses of three of the oldest established banks were cancelled in 2006 when they failed to comply with the physical presence requirement. Of the six banks, 2 were first licensed in 1993-94, 2 in 1996, and 2 in 2004-05.

15. All of the six international banks are restricted operations, limited to providing services to those persons or entities listed in the license application. They are primarily used for tax planning purposes and to carry out in-house treasury functions for their parent organizations. Three hold a B1 license and three a B2 license. ${ }^{8}$ A B2 license is the most restrictive and does not allow deposit taking from the nonresident public. While a B1 licensee may accept deposits from nonresidents, none does so. Thus, risks undertaken by these banks are borne directly by the owners and their affiliates. Total assets of offshore banks amounted to $\$ 112$ million at end-2005.

\section{The most significant aspect of the offshore sector in Samoa is the formation of} international business companies (IBCs) through the seven trust and company service providers (TCSP). As of end-2006, 20,806 companies were registered. On average, over 2004-06, about 4,700 companies were registered annually. All seven TCSPs are wholly owned subsidiaries of foreign groups which provide similar services in other jurisdictions. Of the seven, only one limits its services to arranging the incorporation of companies. The others usually provide other basic services following incorporation including provision of a registered office, and a corporate director and/or secretary to the IBC, using their nominee

\footnotetext{
${ }^{8}$ For a description of the three types of (A, B1, and B2) licenses see Box 1 in the 2002 assessment at http://www.imf.org/external/pubs/ft/scr/2004/cr04171.pdf.
} 
companies. At least one of the TCSPs also provides additional value-added services such as asset protection and tax planning to its clients and accounting services to its affiliates in other jurisdictions. There is limited information on the nature and scale of activities performed by the companies for which the trustee companies provide services. In almost all cases the business is referred by introducers, who are lawyers, accountants, or banks. Legislation permits the formation of other forms of companies, such as limited life companies and protected cell companies, but there is little demand for such activity.

17. Offshore insurance activity is also quite limited. There were only three offshore insurance companies at end-2005 compared with five in 2002. One is a nonlife insurance company engaged in general insurance, assuming risk from countries in Asia. The other two are captives established by non-insurance entities to insure their own group risks.

18. The domestic financial sector is dominated by the banking industry. The assets of the four commercial banks, at end-2006, equaled almost 50 percent of total assets of the sector (including the central bank; Table 1). Two of the banks are foreign owned and two are locally owned. There has been a rapid expansion in bank lending in the past year or so. Loans and advances comprised 80.3 percent of banks' assets at end-September 2006. The main area of lending is to the construction sector, but mortgage and transportation lending have also picked up. There has also been an increase in lending for consumption, mirrored in imports. The central bank monitors the banks' portfolios as part of its off-site supervision. Foreign currency exposure is not an issue as banks' strictly limit their open positions. Lending in foreign currency is also limited and all such lending requires the prior approval of the central bank. All banks comply with the minimum risk-weighted capital adequacy ratio of 15 percent. The banking system is adequately capitalized and at end-September 2006 total capital to risk-weighted assets was 23.8 percent and tier-one capital to risk weighted assets was 17.7 percent. At the same time, non-performing loans to total loans edged down to 3.1 percent from 5.4 percent a year earlier and total provisions to total loans stood at 3 percent at end-September 2006.

\section{In the nonbank sector the National Provident Fund and the Development Bank}

have relatively important shares. The National Provident Fund is the sole pension fund and participation is mandatory for all public and registered private sector entities. The Development Bank of Samoa, is fully state-owned, and provides financing for projects in priority sectors, such as fishing and tourism. The number of money transfer agents has increased significantly since the last assessment (5 to 15). This is a result of the CBS trying to promote remittances into Samoa through formal channels by licensed remitters while minimizing transaction costs. In addition, as of end-2006, there were 18 credit unions; 4 insurance companies; 4 insurance agents; 6 money changers; and 6 money lenders.

\section{The domestic financial sector in Samoa is separated from the offshore sector.}

The offshore entities are not permitted to transact business with Samoan residents. The IBA contains provision for international banks to apply to the Minister of Finance for permission to conduct banking business with residents but so far none has applied to do so. All the international banks are foreign owned and are not owned, either directly or indirectly, by any financial institutions. While the domestic commercial banks are permitted to conduct offshore business none has pursued that line of activity aggressively. Some of the domestic 
banks provide limited banking services to some of the IBCs and international banks in order for them to pay local fees etc.

\section{FINDINGS FROM EARLIER ASSESSMENTS AND AUTHORITIES RESPONSE ${ }^{9}$}

21. The 2002 assessment found significant weaknesses in the supervision of both offshore and domestic banks. ${ }^{10}$ The report noted the following areas for improvement in the supervision of offshore banks: all offshore banks to establish physical presence with mind and management; permit supervisors adequate access to customer information; apply due "fit and proper" criteria for licensing; effectively implement on-site supervision; and apply the same supervisory standards as applied to supervision of domestic banks. On supervision of domestic banks the assessment highlighted the following areas for improvement: develop capacity to undertake on-site examinations and more in depth off-site analysis; strengthen legislative powers related to licensing and supervision; introduce prudential regulation to cover various risks related to lending and other activities; and establish closer links with other supervisors.

22. The authorities have taken steps to address many of the recommendations from the 2002 assessment. Steps taken to improve supervision of international banks have been prioritized based on the nature and scale of the industry. To counter the potential reputation risk the authorities have prohibited shell banks and have introduced physical presence requirements for all international banks. All records of the international banks must now be maintained in Samoa and the supervisor has complete access to all of those records, including individual customer accounts, and the power to enforce compliance with such requirement. However, there are no requirements that decision-making management must be located in Samoa, but fit and proper vetting is required for new applications and in ongoing supervision. On-site examinations of international banks have also been undertaken, although, to date, the scope of the examinations was limited to determining physical presence and compliance with the AML/CFT regime. Prudential guidelines have not yet been issued.

\section{With regard to supervision of domestic banks significant improvements have} been made to implement on-site examinations. The CBS has taken measures to develop capacity including through technical assistance and staff participation in training programs. Examinations are conducted using a risk-based approach which uses complementary quantitative analysis (off-site surveillance) and qualitative judgments to identify and measure levels of risk in the activities of each bank and to target on-site examinations accordingly. The on-site examinations have also helped to strengthen the CBS's relationship with banks' external auditors. Communications with other supervisory agencies are taking place (see below). The CBS is still considering expanding its supervisory guidelines and legislative changes.

\footnotetext{
${ }^{9}$ Appendix II contains an updated list of actions taken by the authorities in response to the 2002 assessment in areas other than banking.

${ }^{10} \underline{\text { http://www.imf.org/external/pubs/ft/scr/2004/cr04171.pdf. }}$
} 


\section{MAin Findings And Recommendations}

A. General Issues

\section{Governance issues}

24. The operational independence of SIFA could potentially be compromised because of the responsibility it shares with the Minister of Finance for the supervision and regulation of international banks (see above). At first sight these arrangements suggest scope for considerable governmental interference in supervision. In practice, however, there is no evidence of significant governmental interference and SIFA officials responsible for banking supervision have been able to work autonomously. The current level of interest in applying for international bank licenses is low and the legislative arrangements are working satisfactorily at present. However, these arrangements continue to provide room for governmental interference in supervisory decision-making. Accordingly, the authorities should keep the institutional arrangements under review and at an opportune time in the future consider transferring the Minster's licensing and other powers under the IBA to SIFA (or the Inspector of International Banks).

25. Two distinct functions assigned to SIFA may potentially create a situation of conflict of interest. SIFA's functions, as listed in the SIFA Act, include duties "to monitor and supervise the conduct of international financial services provided within Samoa", and "to promote Samoa as a center for international financial services". As a supervisor, SIFA may be called upon to undertake difficult decisions which may not be compatible with the objective of promotion. The authorities may wish to consider putting in place mechanisms to resolve the potential for conflict between the two functions or to transfer the promotional function to another body.

\section{Cross-border cooperation and information exchange}

26. Both the CBS and SIFA recognize the importance of effective cooperation and information exchange. Samoa's participation in international groups has facilitated cooperation and information exchange. Samoa is a member of the regional Association of Supervisors of Pacific Countries; an observer in the Offshore Group of Banking Supervisors; a member of the Offshore Group of Insurance Supervisors; and a member of the International Association of Insurance Supervisors. Samoa does not have any Memorandums of Understanding with supervisors in other countries but this does not appear to have hindered cooperation. A sample of foreign supervisors indicated that Samoa has shared information with them in a timely manner. The CBS also communicates, cooperates, and exchanges information with the home country supervisor of two Samoan-licensed subsidiary banks, the Australian Prudential Regulation Authority. The CBS and SIFA maintain relationships and communicate with other supervisors within and outside of the region on matters relating to supervision and licensing. Both the FIA and the IBA authorize the disclosure of confidential supervisory information to foreign supervisors which perform functions that correspond, or are similar, to those of the CBS and the SIFA, respectively. 


\section{Other issues}

27. Samoa is participating in the IMF's Information Dissemination and Monitoring Framework initiative. SIFA has provided most of the minimum requested data. One of the objectives of the initiative was to help jurisdictions in their dissemination efforts, and thereby enhance the transparency of activities undertaken in offshore centers. However, SIFA does not as yet publish or otherwise disseminate data on the offshore sector. Part of this limitation may arise from the legal framework. SIFA is strongly encouraged to consider disseminating aggregate data on the activities of the offshore sector.

28. SIFA should put in place a comprehensive business continuity plan. SIFA has some basic business continuity plans in place in the event of a natural shock (e.g. cyclone). Staff recommends that SIFA, in consultation with other agencies and the finance industry, develop a comprehensive plan, and put in place procedures that would be followed in the event of a natural shock or other similar event (e.g., an avian flu outbreak).

\section{B. Banking Supervision}

\section{Offshore banks}

29. Compliance with the BCPs for bank supervision has improved considerably compared with the previous assessment for supervising international banks. The implementation of the International Banking Act 2005 provides the authorities with powers to supervise and regulate all aspects of international banking operations, and the legal provisions for legal protection and information sharing are now fully compliant. With the requirement for a physical presence the supervisor can now complement off-site supervision with on-site examinations. On-site examinations of international banks have been initiated. A working draft of an on-site examination manual has been prepared. On-site examinations of two key areas of bank operations, AML/CFT and the physical presence requirements, have already been conducted in all banks. Examinations of other areas of potential risk are being considered.

30. While progress has been made in improving the supervisory system further steps need to be taken particularly through prudential guidance on banks' lending activities and other risk taking activities. Given the current size and scope of international banking activity conducted in Samoa, supervision of these banks for the conventional purpose of depositor protection is largely unnecessary. Moreover, the risk of adverse developments in international banks located in Samoa impacting negatively the domestic financial system or the wider international financial system is not material. However, Samoa is still exposed to reputation risk, particularly if supervisory standards are perceived to be lower than acceptable international levels. In this context, the authorities should take the following steps to further strengthen supervision of international banks in line with international standards:

- continue to use on-site examinations to achieve a fuller understanding of these banks' operations, the risks they incur for their owners, the effectiveness of their risk controls; and identify any aspects of their operations which may represent a risk to Samoa's reputation; 
- introduce a minimum capital requirement for each international bank (based on Basel standards) which reflects its individual risk profile;

- issue a regulatory code which provides guidance on the minimum standards which banks are expected to meet in their own policies, procedures, and systems. These should cover all relevant aspects of risk management, including counterparty evaluation, loan review and provisioning, large exposures, connected lending, country risk, market risk, liquidity risk, operational risk, interest rate risk, internal controls and accounting systems, and corporate governance; and

- amend the IBA to control more effectively banks' transactions with connected parties.

\section{Domestic banks}

31. The assessment's findings suggest that in the supervision of domestic banks compliance with the BCPs has improved considerably compared with the previous assessment. An important development has been the introduction of an on-site-examination program to complement the previously existing off-site surveillance program. A comprehensive on-site examination manual with a risk-based approach has been adopted. On-site examinations of two key areas of - credit risk management and AML/CFT - have already been conducted in all banks. Targeted examinations of other areas of potentially significant risk, as identified by the off-site surveillance program and discussions with bank management, are planned to be conducted on a two-year cycle.

\section{The CBS should take the following steps to further strengthen supervision of domestic banks.}

- issue more detailed guidance to banks on the standards which it expects them to observe in their individual credit policies and use these to evaluate the effectiveness of banks' systems and controls for managing credit risk;

- collect information on connected lending; use off-surveillance and examinations to monitor banks' compliance with the restrictions on such exposures; and seek legal power to rule, as need arises, on the existence of specific instances of connected lending;

- introduce a requirement for banks to have in place comprehensive risk management policies, approved at Board level, which enable them effectively to identify, evaluate, monitor and control all their material non-credit risks, including interest rate, market, country, and operational risks; and assess the adequacy of these policies and procedures during on-going supervision.

- seek amendment of the FIA to have authority to control the establishment of subsidiary companies by banks within the existing aggregate ceiling of 60 percent of capital and reserves

- require banks to report all single exposures (as currently defined) which exceed 10 percent of capital since the present quarterly return of each bank's 10 largest borrowers 
may not capture all significant large exposures and does not provide sufficient information for fully effective monitoring of concentration risk; the adequacy of banks' own internal systems for identifying groups of related borrowers and controlling credit concentrations should be an important element of the requirements for banks' own credit policies (mentioned above);

- seek amendment of the FIA to have authority to effect changes in banks' Boards of Directors and senior management;

- provide guidance to the banks on the establishment of corporate governance policies and procedures; and,

- expeditiously complete and gain approval of the new regulations and guidance to implement the new AML/CFT legislative framework. 
Table 1. Samoa: Structure of the Domestic Financial System, 2002-06

(In millions of tala; end of period)

\begin{tabular}{lrrrrr}
\hline & $\mathbf{2 0 0 2}$ & $\mathbf{2 0 0 3}$ & $\mathbf{2 0 0 4}$ & $\mathbf{2 0 0 5}$ & $\mathbf{2 0 0 6}$ \\
\hline & $1,018.3$ & $1,107.3$ & $1,247.3$ & $1,345.7$ & $1,463.5$ \\
Total assets & & & & & \\
Central Bank of Samoa & 147.2 & 145.5 & 196.3 & 196.9 & 184.5 \\
Commercial Banks & 449.9 & 502.0 & 571.6 & 636.3 & 729.6 \\
ANZ & 276.1 & 305.4 & 314.4 & 316.2 & 380.1 \\
Westpac Bank Samoa Ltd & 127.8 & 133.3 & 147.9 & 170.1 & 175.1 \\
National Bank of Samoa & 46.0 & 51.1 & 64.6 & 88.4 & 100.7 \\
Samoa Commercial Bank & 0.0 & 12.2 & 44.7 & 61.6 & 73.7 \\
& & & & & \\
Nonbank financial institutions & 421.2 & 459.8 & 479.3 & 512.5 & 549.4 \\
Insurance sector & 58.3 & 62.2 & 68.0 & 70.4 & 70.5 \\
$\quad$ Samoa Life Assurance Corporation & 27.6 & 30.0 & 29.8 & 30.8 & 31.9 \\
$\quad$ National Pacific Insurance & 30.7 & 32.2 & 31.1 & 30.8 & 33.8 \\
Corporation & & & & & \\
$\quad$ Colonial Life Insurance & 0.0 & 0.0 & 2.1 & 3.6 & 4.8 \\
Progressive Insurance 1/ & 0.0 & 0.0 & 5.0 & 5.2 & $\ldots$ \\
National Provident Fund & 261.7 & 284.3 & 300.7 & 320.2 & 328.8 \\
Development Bank of Samoa & 74.6 & 84.4 & 83.3 & 92.4 & 118.9 \\
Public Trust Office & 10.2 & 11.1 & 9.9 & 9.4 & 9.4 \\
Housing Corporation & 16.4 & 17.8 & 17.4 & 20.1 & 21.8 \\
& & & & & \\
\hline
\end{tabular}

Source: Central Bank of Samoa.

1/ Data for end-June. 


\section{APPENDIX I. REPORT ON THE OBSERVANCE OF STANDARD AND CODES}

This Appendix contains a summary assessment of Samoa's observance of the Basel Core Principles for Effective Banking Supervision (BCPs).

The assessment of the Basel Core Principles was undertaken by Ronald J. MacDonald and Timothy M. Sullivan (supervision experts). The assessment was carried out during a mission to Samoa from February 27 to March 8, 2007. The assessment was based on the laws, regulations, policies, and practices in place at the time the assessment was made. The assessment was based on the following sources of information mainly gathered before and during the mission:

- $\quad$ self assessments of compliance with the BCPs completed by the Central Bank of Samoa (the CBS) and the Samoa International Finance Authority (SIFA) during the mission

- $\quad$ reviews of relevant legislation, prudential regulations and other documentation

- $\quad$ detailed interviews with the supervisory authorities

- $\quad$ meetings with other relevant authorities; and

- $\quad$ meetings with domestic and international banks, the bankers association, and an audit firm.

The assessors also had access to an assessment performed by the Fund in 2002. The present assessment reflects changes that have occurred in the regulatory supervisory framework during the past five years. 


\section{Basel Core Principles for Effective BANKIng SUPERViSion}

\section{General}

33. This assessment of Samoa's compliance with the Basel Core Principles for Effective Banking Supervision was carried out during an IMF mission undertaken in the context of the IMF's offshore financial center assessment program. The assessment was conducted in accordance with the 1997 BCP and the accompanying Methodology (1999). In addition, the team provided the Samoan authorities with advice on compliance with the more recently revised $2006 \mathrm{BCP}$.

\section{Institutional setting and market structure}

34. Samoa's legal framework for bank regulation and supervision is based on the Central Bank of Samoa Act 1984, the Financial Institutions Act 1991(FIA) as amended, the International Banking Act 2005 (IBA), the Samoa International Financial Authority Act 2005, the Prudential Statements issued by the CBS and the various reporting forms issued by the CBS and SIFA.

35. As the central bank, the CBS is both the monetary and supervisory authority for domestic banks. Since 2001 it is also responsible for supervising the Development Bank of Samoa, the National Provident Fund and domestic insurance companies. By law, it has exclusive responsibility for the supervision of the financial institutions it has licensed under the FIA. The CBS has complete autonomy in licensing and supervising domestic banks.

36. Samoa also has an international financial industry which includes six international banks (formerly known as offshore banks). These banks are prohibited from conducting banking business with residents of Samoa. Responsibility for the regulation and supervision of the international banks is shared between the Minister of Finance and the Inspector of International Banks (who is also the chief executive of SIFA). The Minister has exclusive authority to license international banks, to impose license conditions and to revoke their licenses. SIFA is responsible for the day to day supervision of international banks and for submitting licensing proposals to the Minister. Despite the legal powers of the Minister there is no evidence of governmental interference in the supervision carried out by SIFA whose staff are able to work autonomously. The international banks are very small and do not accept deposits from the public. The IBA 2005 compelled them to establish a physical presence in Samoa (although local mind and management is not required) and to maintain all business records there.

37. Co-ordination between the CBS and SIFA is ensured through the ex officio membership of the Chief Executive Officer of the Ministry of Finance on the board of the CBS, while SIFA's operations are directed by a board which is chaired by the Governor of the CBS. Both the CBS and SIFA have legal gateways permitting them to disclose confidential information to each other and to foreign bank supervisors. The Financial Institutions Department of the CBS functions both as the Central Bank's supervisory unit of the CBS and as the country's Financial Intelligence Unit responsible for collecting and processing AML/CFT reports. The CBS publishes a Statistical Bulletin and an Annual 
Report. There are no legal requirements for it or SIFA to review their performance or to report publicly on the discharge of their supervisory responsibilities.

\section{General preconditions for effective banking supervision}

38. The land tenure system in Samoa represents a constraint in terms of enterprise financing since freehold land, which is the major type of collateral required by banks, accounts for only about four percent of the total land, while the largest part, about eighty percent, is customary land, and the rest government-owned. The laws and the court system, however, allow banks to promptly take possession of real property security on defaulting loans, with the exception or customary land which is inalienable. There is a system for the registration of banks' ownership interests in motor vehicles. A nascent credit information and debt collection service has been established. The court system is regarded as sound with legal firms of sufficient quality. The availability and reliability of financial data varies greatly but the new Companies Act is encouraging businesses to prepare financial statements within a specified time. There is an active professional body of accountants in Samoa and international accounting and auditing standards are generally the norm. There is no deposit insurance in Samoa and depositors are treated as general creditors.

\section{Main findings}

39. The Samoan authorities can be commended for effecting a considerable improvement in compliance with the Basel Core Principles since the previous assessment in 2002. In no case has compliance deteriorated. Following the enactment of the International Banking Act 2005 the legal framework for supervising both domestic and international banks is now fully compliant. Substantial improvements have also been made in supervisory techniques, including in particular the introduction of on-site bank examinations for both domestic and international banks and moves towards greater analysis of banking risks. However, considerable strengthening is still required in the supervision of banks' risk management and the monitoring of the financial condition of international banks.

\section{Objectives, autonomy, powers and resources (CP1)}

40. Samoa's legal framework complies with international standards. However, it requires improvement through the introduction of a legal definition of a large exposure, which could be used for reporting purposes, and strengthening of the CBS's powers to control banks' investments in non-financial enterprises. Although not currently required in practice, it is also recommended that the CBS should acquire legal authority to carry out supervision on a consolidated basis.

41. While the present staff resources of the FID appear adequate, the introduction of more frequent on-site examinations and development of a more risk-based approach to supervision are likely to necessitate increased staff numbers. 


\section{Licensing and Structure (CPs 2-5)}

42. Samoa has robust criteria and procedures for the licensing of both domestic and international banks, their permitted activities and investments, and for controlling changes of ownership.

\section{Prudential regulations and requirements (CPs 6-15)}

43. The prudential requirements for domestic banks are generally aligned with international standards. However, comprehensive standards for banks' risk management are still lacking. Specific areas requiring new or improved supervisory requirements are banks' policies for controlling credit risk, connected lending, operating risk, interest rate risk, and, although they are not currently material, market and country risks.

44. On the other hand, prudential requirements for international banks remain completely lacking in nearly all relevant areas. The authorities are recommended to analyze the banks' risk activities thoroughly and then to introduce appropriate requirements for international banks.

45. Samoan supervision of both domestic and international banks' anti-money laundering procedures is in line with international standards. The authorities are, however, recommended to expedite the issue of the regulations and guidelines to implement the recently enacted Money Laundering Prevention Act 2007.

\section{Methods of Ongoing Supervision (CPs 16-20)}

46. The supervisory methods in place for both domestic and international banks are generally satisfactory. In both cases, however, the CBS and SIFA need to develop further their examination programs, and use them more systematically to verify supervisory reports and obtain more information on banks' classified assets, connected lending and country exposures.

\section{Information Requirements (CP 21)}

47. While the accounting and auditing requirements for both domestic and international banks are sound, international banks are not required to make any public disclosure of their performance or financial condition. Both the CBS and SIFA should issue standards on corporate governance to their banks.

\section{Formal Powers of Supervisors (CP 22)}

48. The powers of the supervisors to take necessary remedial measures in respect of both banks and individuals associated with them are generally adequate, although the CBS should initiate an amendment to the FIA to limit the involvement of the court in certain administrative remedial measures Currently, the FIA requires a court order before the CBS may take complete control of bank's business, appoint another person to advise a bank, take control of a bank, liquidate a bank, or place a bank in receivership; in these situations, the court must also approve the specific powers of the CBS or such other appointed persons. 


\section{Cross-border Banking (CPs 23-25)}

49. Since none of the domestic or international banks has any subsidiary inside or outside Samoa, CPs 23 and 24 are not applicable at present. Two of the four domestic banks are, however, subsidiaries of foreign banks. Supervision of these two foreign-owned banks is the same as for Samoan-owned banks and follows best international practice. As mentioned above, the CBS has a gateway to disclose information and uses this to co-operate actively with the home country supervisor. None of the international banks is the affiliate of a foreign bank.

Table 2. Domestic Banking Sector: Recommended Action Plan to Improve Compliance with the Basel Core Principles

\begin{tabular}{|l|l|}
\hline \multicolumn{1}{|c|}{ Reference Principle } & \multicolumn{1}{|c|}{ Recommended Action } \\
\hline CP 1(2) Adequate Resources & $\begin{array}{l}\text { In view of the increased volume of on-site examinations the CBS } \\
\text { should increase the human resources available to the FID. }\end{array}$ \\
\hline CP 5 Investment Criteria & $\begin{array}{l}\text { The FIA should be amended to limit the proportion of the equity } \\
\text { of an individual non-financial enterprise which a bank may } \\
\text { acquire (within the existing aggregate limit of 10 percent of its } \\
\text { capital plus unimpaired reserves). Such investments should be } \\
\text { limited to a maximum of 15 percent of the share capital or voting } \\
\text { rights in a non-financial enterprise. }\end{array}$ \\
\hline CP6 Capital Adequacy & $\begin{array}{l}\text { The CBS should consider introducing some straightforward } \\
\text { specific capital charges for market price risk and foreign exchange } \\
\text { risk. }\end{array}$ \\
\hline Provisions & $\begin{array}{l}\text { The CBS should require banks to have in place mechanisms for } \\
\text { regularly valuing collateral and assessing the strength of } \\
\text { guarantees. }\end{array}$ \\
\hline CP7 Credit Policies & $\begin{array}{l}\text { The CBS should issue more detailed guidance to banks on the } \\
\text { standards which it expects them to observe in their individual } \\
\text { credit policies and use these to evaluate the effectiveness of } \\
\text { banks' policies and procedures for controlling credit risk. }\end{array}$ \\
\hline CP9 Large Exposures & $\begin{array}{l}\text { During examinations the CBS should strengthen its assessment of } \\
\text { the adequacy of banks' own internal systems for identifying } \\
\text { groups of related borrowers and controlling credit concentrations. } \\
\text { Banks should be required to report all single exposures (as } \\
\text { currently defined) which exceed 10 percent of capital (i.e. } \\
\text { including many exposures which fall below the 25 percent } \\
\text { ceiling) since the present quarterly return of each bank's 10 } \\
\text { largest borrowers may not capture all single exposures which } \\
\text { exceed 25 percent of capital and does not provide sufficient } \\
\text { information for fully effective monitoring of concentration risk. }\end{array}$ \\
\hline
\end{tabular}




\begin{tabular}{|c|c|}
\hline Reference Principle & Recommended Action \\
\hline CP10 Connected Lending & $\begin{array}{l}\text { The CBS should have specific discretionary power to make } \\
\text { judgments on specific issues on connected lending. } \\
\text { The CBS should validate compliance with the law and CP6 } \\
\text { through off-site surveillance and on-site examination. } \\
\text { The CBS should periodically collect information on connected } \\
\text { lending exposures. }\end{array}$ \\
\hline CP11 Country Risk & $\begin{array}{l}\text { The PS should be appropriately amended to address country and } \\
\text { transfer risk. } \\
\text { The CBS should periodically collect information on country and } \\
\text { transfer risk exposures. }\end{array}$ \\
\hline CP13 Other Risks & $\begin{array}{l}\text { The CBS should issue appropriate PS guidance on Operational } \\
\text { Risk and Interest Rate Risk. }\end{array}$ \\
\hline CP14 Internal Controls and Audit & $\begin{array}{l}\text { The FIA should be amended to include authority for the CBS to } \\
\text { change a bank's board of directors and/or senior management in } \\
\text { appropriate circumstances and require specific prior approval of } \\
\text { proposed changes in directors and senior management. } \\
\text { The CBS should issue appropriate guidelines on corporate } \\
\text { governance. }\end{array}$ \\
\hline CP15 Money Laundering & $\begin{array}{l}\text { The CBS, as the Money Laundering Authority, should } \\
\text { expeditiously complete the drafting of required new regulations } \\
\text { and guidance. }\end{array}$ \\
\hline $\begin{array}{l}\text { CP16 On-Site and Off-Site } \\
\text { Supervision }\end{array}$ & $\begin{array}{l}\text { The CBS should diligently pursue full implementation of its on- } \\
\text { site examination program. }\end{array}$ \\
\hline CP17 Bank Management Contact & $\begin{array}{l}\text { The CBS should formalize the requirement for timely notification } \\
\text { of substantive changes and material developments. }\end{array}$ \\
\hline CP18 Off-Site Supervision & $\begin{array}{l}\text { The CBS should expand periodic reporting requirements to } \\
\text { include detailed information on classified assets, connected } \\
\text { lending, and country exposures. }\end{array}$ \\
\hline $\begin{array}{l}\text { CP19 Validation of Supervisory } \\
\text { Information }\end{array}$ & $\begin{array}{l}\text { The CBS should expand its on-site examination program to } \\
\text { include validation of supervisory information. }\end{array}$ \\
\hline CP21 Accounting Standards & $\begin{array}{l}\text { The CBS should issue appropriate guidelines on corporate } \\
\text { governance. }\end{array}$ \\
\hline CP22 Remedial Measures & $\begin{array}{l}\text { The CBS should consider possible amendments to the FIA to limit } \\
\text { the involvement of the Court in taking remedial actions. }\end{array}$ \\
\hline
\end{tabular}


Table 3. International Banking Sector: Recommended Action Plan to Improve Compliance with the Basel Core Principles

\begin{tabular}{|c|c|}
\hline Reference Principle & Recommended Action \\
\hline CP5 Investment Criteria & $\begin{array}{l}\text { The IBA should be amended to limit the } \\
\text { proportion of the equity of an individual non- } \\
\text { financial enterprise which an international bank } \\
\text { may acquire (within the existing aggregate limit } \\
\text { of } 60 \text { percent of its capital plus unimpaired } \\
\text { reserves). Each investment in a non-financial } \\
\text { enterprise should be limited to a maximum of } 15 \\
\text { percent of the share capital or voting rights in that } \\
\text { enterprise. }\end{array}$ \\
\hline CP6 Capital Adequacy & $\begin{array}{l}\text { Each International bank should be subject to a } \\
\text { minimum capital requirements which reflect its } \\
\text { individual risk profile. }\end{array}$ \\
\hline CP7 Credit Policies & $\begin{array}{l}\text { The Minister and Inspector should develop a } \\
\text { regulatory code for the standards which they } \\
\text { expect international banks to meet in their } \\
\text { individual credit policies. It could be efficient to } \\
\text { develop such a code in co-operation with similar } \\
\text { work being undertaken by the CBS. }\end{array}$ \\
\hline CP8 Loan Evaluation and Loan Loss Provisions & $\begin{array}{l}\text { The Minister and Inspector should issue a } \\
\text { regulatory code requiring international banks to } \\
\text { have internal systems for regularly reviewing } \\
\text { their loans and other exposures, classifying these } \\
\text { and making any necessary provisions for losses } \\
\text { on a timely basis. }\end{array}$ \\
\hline CP9 Large Exposures & $\begin{array}{l}\text { The Minister and Inspector should issue a } \\
\text { regulatory code which requires international } \\
\text { banks to address concentration risk. This should } \\
\text { include, inter alia, a definition of closely related } \\
\text { groups (which have to be treated as single } \\
\text { borrowers), a requirement to report all individual } \\
\text { exposures which exceed } 10 \text { percent of capital and } \\
\text { a prohibition on incurring single exposures which } \\
\text { exceed } 25 \text { percent of capital without the prior } \\
\text { permission of the Inspector. }\end{array}$ \\
\hline CP10 Connected Lending & $\begin{array}{l}\text { The IBAA should be amended to prevent } \\
\text { connected lending on more favorable terms than } \\
\text { is available to unconnected parties and to require } \\
\text { that such lending is approved by the bank's board } \\
\text { of directors, with the affected director or other } \\
\text { connected person excluded from the assessment } \\
\text { of and decision-making on the transaction. } \\
\text { The Inspector should require independent } \\
\text { information systems for such exposures. }\end{array}$ \\
\hline
\end{tabular}




\begin{tabular}{|c|c|}
\hline Reference Principle & Recommended Action \\
\hline CP11 Country Risk & $\begin{array}{l}\text { The Inspector should issue appropriate guidance } \\
\text { on all aspects of country risk management and } \\
\text { related information systems and internal controls. } \\
\text { The Inspector should periodically collect } \\
\text { information on country and transfer risk } \\
\text { exposures. }\end{array}$ \\
\hline CP12 Market Risk & $\begin{array}{l}\text { The Inspector should assess the level of market } \\
\text { risk in the international banks and issue } \\
\text { appropriate risk management, internal control, } \\
\text { and information systems requirements and } \\
\text { limitations. } \\
\text { The Inspector should periodically collect } \\
\text { appropriate information on market risk exposures. }\end{array}$ \\
\hline CP13 Other Risks & $\begin{array}{l}\text { The Inspector should issue appropriate guidance } \\
\text { on liquidity risk, operational risk, and interest rate } \\
\text { risk. }\end{array}$ \\
\hline CP14 Internal Controls and Audit & $\begin{array}{l}\text { The Inspector should issue specific guidance on } \\
\text { internal controls and audit. } \\
\text { The Inspector should issue specific guidance on } \\
\text { corporate governance. } \\
\text { The Inspector should fully implement the on-site } \\
\text { examination program to address risk } \\
\text { management, internal controls, and audit systems. }\end{array}$ \\
\hline CP15 Money Laundering & $\begin{array}{l}\text { The Inspector should take part, as necessary, in } \\
\text { the drafting of required new regulations and } \\
\text { guidelines. }\end{array}$ \\
\hline CP16 On-Site and Off-Site Supervision & $\begin{array}{l}\text { The Inspector should diligently pursue full } \\
\text { implementation of its on-site examination } \\
\text { program. } \\
\text { The Inspector should expand the on-site } \\
\text { examination program to achieve comprehensive } \\
\text { coverage of all aspects of the banks' activities and } \\
\text { operations. }\end{array}$ \\
\hline CP17 Bank Management Contact & $\begin{array}{l}\text { The Inspector should hold more frequent } \\
\text { meetings with overseas directors and senior } \\
\text { management of the international banks. }\end{array}$ \\
\hline CP18 Off-Site Supervision & $\begin{array}{l}\text { The Inspector should expand periodic reporting to } \\
\text { include information on classified assets, country } \\
\text { exposure, liquidity, and interest rate risk. }\end{array}$ \\
\hline CP19 Validation of Supervisory Information & $\begin{array}{l}\text { The Inspector should expand the on-site } \\
\text { examination program to include validation of } \\
\text { supervisory information. }\end{array}$ \\
\hline CP21 Accounting Standards & $\begin{array}{l}\text { The Inspector should provide for the public } \\
\text { disclosure of information on international banks } \\
\text { that accept deposits from the general public, when } \\
\text { applicable. } \\
\text { The Inspector should provide guidance on } \\
\text { corporate governance to the international banks. }\end{array}$ \\
\hline
\end{tabular}




\section{Authorities' response to the assessment}

50. In reference to the OFC Assessment of Samoa's financial system undertaken by the IMF from 27 February to 8 March 2007, the assessment recognizes considerable improvements being achieved over the past years in terms of the prudential oversight of the licensed financial institutions. Such progress encompasses efforts by the Central Bank of Samoa (CBS) and the Samoa International Finance Authority (SIFA) towards strengthening the existing legislative and regulatory frameworks, policies and procedures for the prudential supervision of both domestic and international banks in Samoa.

51. Equally important, such improvements bring Samoa's financial system significantly in line with internationally recognized standards as promulgated by the Basel Core Principles of the Basel Committee as compared to the previous IMF assessment.

52. On the domestic front, several recommendations to further improve the regulatory role of the CBS in accordance with current international standards have been noted and future efforts shall focus to incorporate and develop as appropriate, the necessary changes in terms of the relevant legislation, prudential statements, regulations, guidelines and the staff capacity towards proper management of the CBS's supervisory responsibility.

53. With regards to the international finance sector, the regulatory authority (SIFA) notes the recommended action plan and shall review the current legislation and prevailing prudential requirements as a result, with a view to further improving the supervision of international banks as per international standards. 


\section{APPENDiX II. ACtions TAKen by the SAMOAN AUthorities In RESPONSE TO THE 2002 ASSESSMENT}

The Table below provides an update on the actions taken by Samoa in response to the recommendations of the 2002 IMF assessment in the areas of AML/CFT, company and trust service providers, and other related areas. ${ }^{11}$

\begin{tabular}{|c|c|}
\hline \multicolumn{2}{|r|}{ ANTI-MONEY LAUNDERING MEASURES } \\
\hline Recommendation & Response \\
\hline $\begin{array}{l}\text { Amend the definition of financial } \\
\text { institution so that all offshore entities } \\
\text { and specifically trustee companies are } \\
\text { included in the definition. }\end{array}$ & $\begin{array}{l}\text { All offshore entities are caught under the Money Laundering } \\
\text { Prevention Act } 2007 \text { by virtue of activities deemed to be financial } \\
\text { institutions under Schedule } 1 . \\
\text { i.e./International banking business as defined in the International } \\
\text { Banking Act } 2005 \text { (no. 19) is expressly included in the Schedule in } \\
\text { addition to Trustee Company business as defined by the terms "carry } \\
\text { on business" and "trustee company" in section } 2 \text { of the Trustee } \\
\text { Companies Act } 1987 \text { etcetera. The activities of Insurance } \\
\text { Companies, and trusts, are also caught under the Act. }\end{array}$ \\
\hline $\begin{array}{l}\text { Broaden the scope of the MLPA to } \\
\text { include comprehensive and all } \\
\text { substantive requirements relating to } \\
\text { customer identification and } \\
\text { verification, record keeping and } \\
\text { retention and suspicious transaction } \\
\text { reporting. }\end{array}$ & $\begin{array}{l}\text { The new MLPA } 2007 \text { under Part III headed "Obligations To Keep } \\
\text { Records and Verify Identity" explicitly outlines all substantive } \\
\text { requirements relating to customer identification, verification, record } \\
\text { keeping, and maintenance, plus suspicious transaction reports. } \\
\text { Please refer to sections } 16,17,18,19,20,21 \text { and } 22 \text { of the Act. } \\
\text { The express mandatory obligation is for all financial institutions to } \\
\text { report suspicious transactions where there are reasonable grounds to } \\
\text { suspect or it has information that a transaction, or an attempted } \\
\text { transaction that may be. } \\
\text { i. } \quad \begin{array}{l}\text { relevant to an investigation/prosecution of a person for a } \\
\text { serious offence, a money laundering offence or an offence } \\
\text { of assistance to the enforcement of Proceeds of Crime Act }\end{array} \\
\text { ii. } \quad \begin{array}{l}\text { or } \\
\text { related to the commission of a serious offence a Money } \\
\text { iii. }\end{array} \\
\text { iv. } \quad \begin{array}{l}\text { Laundering or terrorist financing offence. } \\
\text { preparatory to an offence of terrorist financing. }\end{array}\end{array}$ \\
\hline
\end{tabular}

${ }^{11}$ The "Recommendation" column list the recommendations as reported in the 2002 assessment report and the "Response" column has been updated by the authorities to reflect the actions taken since the 2002 assessment. 


\begin{tabular}{|c|c|}
\hline $\begin{array}{l}\text { Amend the MLPA to improve the } \\
\text { framework for reporting suspicious } \\
\text { transactions to include extending the } \\
\text { tipping-off provisions and improving } \\
\text { the protection for the information } \\
\text { reported and the persons reporting. }\end{array}$ & $\begin{array}{l}\text { The new anti tipping off provisions under Section } 27 \text { have been } \\
\text { widened to clarify that a supervisory authority its officers, } \\
\text { employees or agents, or auditor shall not disclose to any person that:- } \\
\text { i. } \quad \text { a report to the FIU had been made } \\
\text { ii. a financial institution, supervisory authority or auditor has } \\
\text { formed a suspicion relative to a transaction } \\
\text { iii. any information from a person can reasonable be expected } \\
\text { to form a suspicion } \\
\text { The protection for information reported is strengthened to include } \\
\text { any information that will identify or likely to identify:- } \\
\text { i. any person who handled a transaction with respect to an STR } \\
\text { already made } \\
\text { ii. any person who prepared an STR } \\
\text { iii. any person who made an STR } \\
\text { iv. any information contained in an STR } \\
\text { Additionally no person is required to disclose any information } \\
\text { (except for the investigation, prosecution of a serious offence, a } \\
\text { Money Laundering offence or terrorist financing offence or the } \\
\text { enforcement of the Proceeds of Crimes Act) in any judicial } \\
\text { proceedings unless the judge is satisfied the disclosure is necessary } \\
\text { in the interests of justice. } \\
\text { Moreover, no civil, criminal, administrative or disciplinary } \\
\text { proceedings can be taken against a financial institution (including its } \\
\text { officers, employees or agents) an auditor or supervisory authority of } \\
\text { a financial institution, a financial institution of or any of their actions } \\
\text { taken in good faith or in compliance with directions of the Financial } \\
\text { Intelligence Unit (FIU). } \\
\text { Other information that is protected and must not be disclosed despite } \\
\text { the necessity of identification to conduct business and the } \\
\text { obligations to make suspicious transaction reports is privileged } \\
\text { communications between a lawyer and his client which is clarified in } \\
\text { Section } 30 \text { of the Act. } \\
\text { i.e./Confidential information which is either oral or written } \\
\text { communication } \\
\text { i. } \quad \text { between lawyers in their professional capacity } \\
\text { ii. between a lawyer and his client in a professional capacity } \\
\text { either directly/indirectly through an agent and either } \\
\text { iii. made or brought into existence for the purpose of obtaining } \\
\text { cogal advise or assistance } \\
\text { comission of some illegal or wrongful act. }\end{array}$ \\
\hline $\begin{array}{l}\text { Putting in place the administrative and } \\
\text { operational steps toward establishing } \\
\text { the FIU and providing for the } \\
\text { governance and oversight structure for } \\
\text { the FIU. }\end{array}$ & $\begin{array}{l}\text { The FIU has been physically established with staff dedicated to } \\
\text { receive, analyse and maintain systems. An AML/CFT mentor } \\
\text { seconded to the MLA under the auspices of the PALP initiative is } \\
\text { awaited. }\end{array}$ \\
\hline
\end{tabular}




\begin{tabular}{|c|c|}
\hline & $\begin{array}{l}\text { Furthermore, the Samoa FIU had received the assistance by } \\
\text { AUSTRAC with respect to a specialized data based computer system } \\
\text { (FIU-in -the box) for proper storage and analysis of information its } \\
\text { receives from financial institutions, for instance, Suspicious } \\
\text { Transaction Report (STR). } \\
\text { Operational manuals and guidelines for the operation and } \\
\text { management of the FIU have been developed. }\end{array}$ \\
\hline $\begin{array}{l}\text { Amend the MLPA to include } \\
\text { comprehensive forfeiture of proceeds } \\
\text { of crime and confiscation of benefits } \\
\text { provisions, as well as the power to } \\
\text { make penalty orders where forfeiture } \\
\text { is not possible. }\end{array}$ & $\begin{array}{l}\text { Two (2) new pieces of legislation were enacted on } 7 \text { February } 2007 \\
\text { which deals with the above recommendation in a comprehensive } \\
\text { manner viz a viz the Proceeds of Crime Act and the Mutual Legal } \\
\text { Assistance in Criminal Matters Act } 2007 .\end{array}$ \\
\hline $\begin{array}{l}\text { Introduce common provisions in all } \\
\text { the regulatory laws requiring that } \\
\text { shareholders and directors of financial } \\
\text { service providers be "fit and proper" } \\
\text { persons, thus preventing serious } \\
\text { criminals from controlling financial } \\
\text { service providers. }\end{array}$ & $\begin{array}{l}\text { The new IBA expressly provides in section } 3 \text { the definition of "fit } \\
\text { and proper" to determine all persons in their compliance with the } \\
\text { Act. The criteria requires regard to all circumstances including } \\
\text { honesty, integrity and reputation, competence and capability and } \\
\text { financial soundness. } \\
\text { This definition is also mirrored in the Trustee Companies Bill which } \\
\text { reflects requirements stipulated in the Application Form and } \\
\text { Personal Questionnaire to be completed by all directors, controllers } \\
\text { and managers of a trustee company. }\end{array}$ \\
\hline $\begin{array}{l}\text { Amend the MLA with the full range of } \\
\text { powers and functions of an operational } \\
\text { FIU, including the power to analyze } \\
\text { information and to exchange } \\
\text { information with foreign FIU's and } \\
\text { law enforcement agencies. }\end{array}$ & $\begin{array}{l}\text { The MLPA } 2007 \text { establishes an FIU within the MLA in the CBS } \\
\text { with a wide range of functions and powers including the following:- } \\
\text { a. to receive reports and information by any agency of a } \\
\text { foreign state, law enforcement agency, government institution or } \\
\text { agency regarding suspicions of a serious offence, money laundering } \\
\text { offence or a terrorist financing offence. } \\
\text { b. to collect information that is publicly available including } \\
\text { commercially available databases or information that is collected or } \\
\text { maintained by government that is relevant to a serious offence, } \\
\text { money laundering or terrorist financing offence. } \\
\text { c. } \quad \text { to analyse and assess all reports and information } \\
\text { d. to request information from any law enforcement agency, } \\
\text { government agency or supervisory agency for purposes of the Act. } \\
\text { e. to enter into an MOU agreement with national authorities } \\
\text { including non governmental agencies and authorities including } \\
\text { Police, Customs, Immigration, CBS and SIFA to ensure close } \\
\text { liaison, cooperation and secure exchange of information. } \\
\text { f. can spontaneously provide information on a serious money } \\
\text { laundering or terrorist financing offence to foreign agencies } \\
\text { concerned with the prevention, investigation of ML/TF } \\
\text { g. provide any report, information to appropriate law } \\
\text { enforcement and supervisory authorities if the FIU has reasonable } \\
\text { grounds to suspect a suspicious transaction. }\end{array}$ \\
\hline
\end{tabular}




\begin{tabular}{|c|c|}
\hline & $\begin{array}{l}\text { h. can provide information to a regulatory authority, } \\
\text { government, or law enforcement agency of an alleged breach by a } \\
\text { financial institution, with a request for a license to be reviewed. } \\
\text { i. must destroy an STR received } 5 \text { years after the date of its } \\
\text { receipt if there has been no further activity since receipt of a report. }\end{array}$ \\
\hline $\begin{array}{l}\text { Amend the MLPA to extend the scope } \\
\text { of the mutual assistance provisions to } \\
\text { cover all criminal offences. }\end{array}$ & $\begin{array}{l}\text { The provisions to facilitate Mutual Assistance on ML matters are } \\
\text { now contained in the Proceeds of Crimes Act } 2007 \text {. } \\
\text { The meaning of "proceeds of crime" in section } 6 \text { of the Act is "any } \\
\text { property wholly or partly derived or realised whether directly or } \\
\text { indirectly from a serious offence whether situated within or outside } \\
\text { Samoa. Property can be proceeds of crime even if no person has } \\
\text { been convicted of an offence. } \\
\text { "Serious offence" in section } 2 \text { of the Proceeds of Crime Act } 2007 \\
\text { means an offence. } \\
\text { against any law of Samoa that would constitute unlawful } \\
\text { activity or } \\
\text { b. } \\
\text { omission occurred in Samoa would be an offence that constitutes } \\
\text { unlawful activity. } \\
\text { The definition of "unlawful activity" in the Proceeds of Crimes Act } \\
2007 \text { means any act or omission that constitutes an offence that is } \\
\text { punishable under the laws of Samoa for a maximum period of not } \\
\text { less than } 12 \text { months. } \\
\text { A reference in the Act to the law of Samoa or any foreign state } \\
\text { includes reference to a written or unwritten law of in force in any } \\
\text { part of Samoa or a foreign State. Such definition is all embracing } \\
\text { and conceivably covers all criminal offences. }\end{array}$ \\
\hline 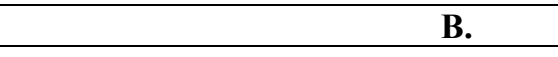 & COMPANY SERVICE PROVIDERS \\
\hline Recommendation & Response \\
\hline $\begin{array}{l}\text { Trustee companies should conduct an } \\
\text { enhanced level of due diligence, } \\
\text { especially with regard to all new } \\
\text { business transferring to the jurisdiction } \\
\text { under redomiciliation. }\end{array}$ & $\begin{array}{l}\text { As "financial institutions" under the Money Laundering Prevention } \\
\text { Act } 2007 \text { (section 16) trustee companies are compelled to identify } \\
\text { and verify the identity of a customer and obtain satisfactory evidence } \\
\text { of identity when:- } \\
\text { a. establishing a business relationship or } \\
\text { b. conducting any transaction or } \\
\text { c. there is suspicion of a ML/TF offence or } \\
\text { d. the financial institution has doubts about the veracity or } \\
\text { adequacy of customer identification, verification of documentation } \\
\text { or information previously obtained. } \\
\text { Additionally, under section } 17 \text { of the MLPA 2007, if a trustee } \\
\text { company is not able to obtain satisfactory evidence of the identity of } \\
\text { a customer, it must not proceed any further and must report the } \\
\text { attempted transaction to the Financial Intelligence Unit (FIU). }\end{array}$ \\
\hline
\end{tabular}




\begin{tabular}{|c|c|}
\hline & $\begin{array}{l}\text { Further, a trustee company under section } 18 \text { is obliged to keep } \\
\text { records for } 5 \text { years of all business transactions and correspondence } \\
\text { thereon including identification records of customers, and enquiries } \\
\text { to and from the FIU. } \\
\text { Also as a financial institution, a trustee company is obliged to } \\
\text { monitor transactions and examine as far as possible the background } \\
\text { and purpose of unusual or large transactions, electronic transfers and } \\
\text { any transactions with persons in jurisdictions with inadequate } \\
\text { AML/CFT systems. } \\
\text { The draft Trustee Companies Bill } 2005 \text { specifies as a statutory duty } \\
\text { of the Regulator (Inspector of Trustee Companies) the review of } \\
\text { activities of trustee companies which includes AML policies and } \\
\text { procedures for "Know Your Customer" and anti Money Laundering. } \\
\text { The Authority is also empowered under clause } 6 \text { of the Bill to make } \\
\text { Regulatory Codes for the conduct of trust company business, Know } \\
\text { Your Customer and Customer due diligence procedures. } \\
\text { A Draft Regulatory Code compiled by an IMF Technical Expert in } \\
\text { May } 2006 \text { includes Detailed Fit and Proper Criteria for applications } \\
\text { from new companies. }\end{array}$ \\
\hline $\begin{array}{l}\text { Conduct regular on-site visits to the } \\
\text { trustee companies and consider } \\
\text { entering into specific exchange of } \\
\text { information agreements with the host } \\
\text { country supervisors. }\end{array}$ & $\begin{array}{l}\text { SIFA has implemented preparatory training sessions, with the } \\
\text { assistance of the IMF, for conducting such on-site inspections. } \\
\text { In late } 2005 \text { and early 2006, SIFA staff jointly with Money } \\
\text { Laundering Prevention Authority (MLPA) personnel conducted } \\
\text { several onsite visits on trustee companies, banks and money } \\
\text { changers. One of the trustee companies lost their license in 2006, as } \\
\text { a result of the findings of the on-site inspection visits. }\end{array}$ \\
\hline & OTHER ISSUES \\
\hline Recommendation & Response \\
\hline $\begin{array}{l}\text { Modernize the insurance legislation } \\
\text { which will establish the CBS as the } \\
\text { licensing and supervisory entity of the } \\
\text { domestic insurance companies. }\end{array}$ & $\begin{array}{l}\text { The Insurance Bill } 2007 \text { has been through its second reading in } \\
\text { Parliament in early February. The Bill is now at the Parliamentary } \\
\text { Committee stage for final review before seeking Parliament's } \\
\text { approval at its next Sitting around end June } 2007 \text {. }\end{array}$ \\
\hline $\begin{array}{l}\text { In licensing general insurance } \\
\text { business, require that international } \\
\text { insurance companies be in compliance } \\
\text { with other country's laws where the } \\
\text { insurance products are sold. }\end{array}$ & $\begin{array}{l}\text { The Samoan authorities have adopted the recommended policy in } \\
\text { dealing with all future international insurance applications. } \\
\text { The license application form will be amended to reflect this change. }\end{array}$ \\
\hline $\begin{array}{l}\text { Establish close communication and } \\
\text { information sharing with the insurance } \\
\text { regulators in other countries. }\end{array}$ & $\begin{array}{l}\text { As a member of the Offshore Group of Insurance Supervisors } \\
\text { (OGIS) and the International Association of Insurance Supervisors } \\
\text { (IAIS), SIFA has established close communication with other } \\
\text { insurance regulators. } \\
\text { Provision is made in the International Insurance Act } 1988 \text { for sharing } \\
\text { of information between regulators. }\end{array}$ \\
\hline
\end{tabular}




\begin{tabular}{|l|l|}
\hline $\begin{array}{l}\text { Introduce a basic investment business } \\
\text { and securities legislation to regulate } \\
\text { fraudulent provision of financial } \\
\text { advice and product sales to both } \\
\text { domestic and international markets. }\end{array}$ & $\begin{array}{l}\text { Amendments to the Financial Institutions Act have been prepared to } \\
\text { regulate investment and securities business under the CBS. }\end{array}$ \\
\hline $\begin{array}{l}\text { Introduce legislation on collective } \\
\text { investment schemes while prohibiting } \\
\text { the establishment of unlisted collective } \\
\text { investment schemes. }\end{array}$ & $\begin{array}{l}\text { An International Mutual Funds Bill that had been drafted in 2004 is } \\
\text { at the Attorney General's Office and awaits approval before being } \\
\text { referred to Cabinet. }\end{array}$ \\
\hline
\end{tabular}

